\title{
CIVIL PROCEDURE: POWER OF TRIAL JUDGE TO GRANT NEW TRIAL. WHERE VERDICT IS AGAINST WEIGHT OF THE EVIDENCE
}

\section{$\mathbf{T}$} HE RECENT CASE of Lind v. Schenley Industries, Inc., ${ }^{1}$ is a significant development in the law governing the trial judge's power to grant a new trial when he believes that the verdict is against the weight of the evidence. ${ }^{2}$ Plaintiff, an employee of defendant's corporate predecessor, ${ }^{3}$ sued to recover money allegedly due under an incentive compensation plan. ${ }^{4}$ After the jury returned a special verdict for the plaintiff, the federal district judge granted the defendant's motions for judgment n.o.v., and, in the alternative, for a new trial if the judgment n.o.v. were reversed on appeal. ${ }^{5}$ The alternative motion for new trial was granted because the trial judge found the verdict "(I) contrary to the weight of the evidence, (2) contrary to law and (3) a result of error in the admission of evidence." The Court of Appeals for the Third

\footnotetext{
${ }^{2} 278$ F.2d 79 (3d Cir.), cert. denied, 364 U.S. 835 ( 1960 ).

${ }^{2}$ A federal district judge may grant a new trial under Rule 59 of the Federal Rules of Civil Procedure. "Rule 59 (a) Grounds. A new trial may be granted to all or any of the parties and on all or part of the issues ( $x$ ) in an action in which there has been a trial by jury, for any of the reasons for which new trials have heretofore been granted in actions at law in the courts of the United States. ..."

${ }^{3}$ The plaintiff had originally sued Park \& Tilford Distiller's Corporation, which later merged with Schenley Industries, Inc., the latter assuming all of the former's obligations. Schenley Industries was substituted as defendant in the Lind case by order of the trial judge.

"Plaintiff was assistant to the metropolitan New York sales manager of Park \& Tilford and was later New York district manager for the corporation. Lind alleged that he had been informed of the plan by his supervisor who had authority, actual or apparent, to bind the corporation. The defendant introduced conflicting evidence however. Lind had been receiving a salary of $\$ 125-175$ per week. The alleged compensation plan would have given Lind $\mathrm{x} \%$ of the gross sales of salesmen under his supervision. The jury found that the plan was in effect for ten months, and the trial judge awarded Lind damages of $\$ 36,953.10$.

"FED. R. CIv. P. 59(b). "Within ro days after the reception of a verdict, a party who has moved for a directed verdict may move to have the verdict and any judgment entered thereon set aside and to have judgment entered in accordance with his motion for a directed verdict. . . . A motion for a new trial may be joined with this motion, or a new trial may be prayed for in the alternative." The trial judge is to rule simultaneausly upon the motions for judgment n.o.v. and new trial if both are sought. Montgomery Ward v. Duncan, 3 II U.S. 243 (1940).

${ }^{\circ}$ Lind v. Schenley Industries, Inc., r67 F. Supp. 590,596 (D.N.J. 1958).
} 
Circuit reversed both the judgment n.o.v. and the alternative order granting a new trial, ? and reinstated the jury verdict. ${ }^{8}$ After rejecting the last two grounds for the granting of the new trial, the court held that the trial judge had abused his discretion in granting a new trial on the first ground assigned. Two judges dissented, pointing out that the Third Circuit had "never before reversed an order of a trial judge granting a new trial because of his conclusion on all of the evidence that the jury had reached an unjust result." "This departure from prior decisions warrants a close investigation of appellate regulation of the trial judge's power to grant a new trial when he believes that the verdict is against the weight of the evidence.

The right of a trial judge to grant a new trial on this ground was not recognized at early common law, when juries were deemed to decide cases of their own knowledge. ${ }^{10}$ Rather, writ of attaint was used

\footnotetext{
${ }^{7}$ In reversing the judgment n.o.v., the court concluded that the jury verdict was not contrary to the New York agency and contract law applicable in the action. This ruling automatically excluded the trial court's second ground for the granting of the new trial. The court also, concluded that certain business records were properly introduced into evidence, thus eliminating the third ground for the granting of the neww trial.

${ }^{8}$ The decision in the Lind icase may also be questioned on an issue beyond consideration in this note. Because of the "final judgment rule" (28:U.S.C. $\S_{4291}$ (1958)), a serious question arises as to the propriety, once a judgment n.o.v. is reversed by a Court of Appeals, of considering at that time, before remand for the new trial and a later final judgment, the appellant's challenge of the new trial order. In Montgomery Ward v. Duncan, 3 I I U.S. 243, 254 (1940) the Supreme Court stated:

"Should the trial judge enter judgment n.o.v. and in the alternative, grant a new trial on any of the grounds assigned therefor, his disposition of the motion for a new trial would not ordinarily be reviewable, and only his action in entering judgment woutld be ground of appeal. If the judgment were reversed, the case, on remand, would be governed by the trial judge's award of a new trial."

The Court cited in this connection Fairmount Glass Works v. Cub Fork Coal Co., 2037 U.S. 474 (1933), which recognized review of decisions on new trial motions 'for errors of law but not for rulings within the discretion of the trial court. In later decisions, most courts of appeals have felt themselves prevented from passing upon the correctness of a new trial order granted on the ground in question after reversing a judgment n.o.v. Menneti v. Evans Constr. Co., 259 F.2d 367 (3d Cir. 1958); Binder v. Commercial Travelers Mut. Acc. Ass'n of America, r6j F.2d 896 (2d Cir. 1948), dîscussed with approval in 5 MOORE, FederaL Practice, I 50.13, at 2346 (2d ed. 195i)'. Contra, Moist Cold Refrigerator Co. v. Lou Johnson Co., 249 F.2d 246 (gth Cir.) (dictum), cert. denied, 356 U.S. 968 ( 1958 ), approved in 3 BÁRron \& HoltzofF, Federal Practice and Procedure $\$$ r 302.1 , at 347 (rev. ed. 1958).

${ }^{\circ}$ Lind v. Schenley Industries, Inc., 278 F.2d 79, 91 (3d Cir. 1960).

${ }^{10}$ Slàde's Case, Style ${ }_{3} \$$; 82 Eng. Rep. "s 52 (K.B. 1648). See 6 Moore, Federal PrACTICE, I 59.05[x] (2d ed. $195 \mathrm{I}$ ) for a general history of the development of the granting of new trials.
} 
to secure reconsideration of the correctness of the jury verdict. ${ }^{11}$ This procedure fell into disuse, however, and new trials came to be granted by courts in banc. ${ }^{12}$ The practice was firmly established in 1757 , when Lord Mansfield commented $:^{13}$

Trial by jury, in civil causes, could not subsist now, without a power, somewhere, to grant new trials ... . But a general verdict can only be set right by a new trial; which is no more than having the same cause more deliberately considered by anotber jury; when there is a reasonable doubt or perhaps a certainty, that justice has not been done.

American appellate courts early recognized the power of the trial judge to grant new trials, not only for errors of law, but also on such discretionary grounds as the verdict's being against the weight of the evidence. ${ }^{14}$ When reviewing these discretionary rulings, appellate courts consistently state that they will reverse only for "abuse of discretion."15 They have experienced difficulty, however, in formulating criteria to indicate just when a trial judge abuses his discretion by granting a new trial because he believes the verdict is against the weight of the evidence. Until the early twentieth century, it was generally stated that a new trial should be granted on this ground only if the verdict was "manifestly and palpably"16 or "decidedly and strongly"17 or

\footnotetext{
${ }^{11}$ If the second jury found the verdict to be incorrect, the original jurors were "imprisoned for a year, forfeited their goods, became infamous, their wives and children were turned out, and their lands laid waste." I HoLDsworth, History of ENGLish LAw 34 I (7th ed. rev. 1956).

${ }^{13}$ Writ of attaint was used primarily to discourage perjury by jurors during the time when the jurors served as witnesses. As this jury function ceased, the writ lost its original purpose. Public opinion turned against the harsh penalties imposed upon the original jurors and the writ of attaint was little used in the sixteenth century. Its demise was confirmed by Bushell's Case, Vaugh. 135, 124 Eng. Rep. roo6 (C.P. 1670).

${ }^{13}$ Bright v. Enyon, I Burr. 390, 393, 97 Eng. Rep. 365, 366 (K.B. I 757).

${ }^{14}$ Kohne v. Insurance Co. of No. America, 14 Fed. Cas. 838 (No. 7921 ) (C.C.D. Pa. I804); Curtis v. Jackson, 13 Mass. (12 Tyng) 507 (1816). In America it was necessary for the trial judge to exercise the power to grant new trials, since the practice of having the trial judge also sit on a court in banc was not adopted from the English practice. Hinton, Power of Federal Appellate Court to Review Rulings on Motion for New Trial, I U. CHr. L. REv. III (I933).

${ }^{25}$ Williams v. Nichols, 266 F.2d 389 (4th Cir. 1959); De Pascale v. Pennsylvania R.R., 180 F.2d 825 (3d Cir. 1950); Guy Frye \& Sons, Inc., v. Francis, 242 N.C, 107, 86 S.E.2d 790 (1955).

${ }^{10}$ Scott v. Blumb, 7 Ill. (2 Gilm.) 595 (1845); Whipple v. Michigan Cent. R.R., I 30 Mich. 460, 90 N.W. 287 ( .902).

… Finney v. Sanford, 4I Ga. 295 (1870).
} 
"plainly"18 or "clearly"19 against the weight of the evidence. Such statements have fallen into disuse, ${ }^{20}$ however, perhaps because they fail to provide articulate and functional guides for the trial judge:

More recent formulations attempt no more than to indicate the perspective in which the trial judge should consider motions for new trial. Appellate courts have admonished trial judges to use "mature judicial discretion," "exercised with regard to what is right and in the interests of justice."22 The motion for new trial tests "the overall justice of the case result." ${ }^{23}$

The Lind decision far exceeds prior appellate efforts to delineate and restrict the area within which the trial judge may properly grant a new trial on the ground that the verdict is against the weight of the evidence. The Third Circuit first distinguishes new trials granted on this ground froin "new trials ordered for other reasons: for example, evidence improperly admitted, prejudicial statements by counsel, an improper charge to the jury or newly discovered evidence."’24 These latter grounds are denominated "undesirable or pernicious elements."25

\footnotetext{
${ }^{28}$ Marshall's Adm'x v. Valley R.R., 97 Va. 653, 34 S.E. 455 ( 8999 ).

${ }^{20}$ Jameson v. Weld, 93 Me. 345, 45 Atl. 299 (1899); Garrett v. Driver-Harris Wire Co., 7 o N.J.L. $3_{82,57}$ Atl. I27 (1904).

${ }^{20}$ This language is found only occasionally in modern opinions. Moist Cold Refrigerator Co. v. Lou Johnson Co., 249 F.2d 246, 256 (gth Cir.), cert. denied, 356 U.S. I68 (x958); Gregory v. James, x 53 Me. 453, 457, 140 A.2d 725, 728 (1958); Mulroy v. Co-operative Transit Co., $x 42$ W.Va. $x 65, \times 81,95$ S.E.2d 63, 72 (1956).

${ }^{21}$ Miller v. Tennessee Gas. Transmission Co., 220 F.2d 434 (5th Cir. 1955). Similarly, it is said that the trial judge should use sound discretion. Morris Bros. Lumber Co. v. Eakin, 262 F.2d 259 (3d Cir. 1959); Norfolk So. Ry. v. Davis Frozen Foods, Inc., r 95 F.2d 662 (4th Cir. 1952); Caudle v. Swanson, 248 N.C. 249, 103 S.E.2d 357 (x958).

${ }^{22}$ Commercial Credit Corp. v. Pepper, 187 F.zd 7x (5th Cir. $195 x$ ). Other cases have said that the trial judge should exercise his discretion in order to "prevent a miscarriage of justice." Whiteman v. Pitrie, 220 F.2d 914 (5th Cir. 1955); Garrison v. United States, 62 F.2d 4I (4th Cir. r932).

${ }^{23}$ Wilson v. Bailey, 257 F.2d 352 (roth Cir. 1958).

"The court distinguishes the two categories on the following basis:

"In the first instance given it is the jury itself which fails properly to perform the functions confided to it by law. In the latter instances something occurred in the course of the trial which resulted or which may have resulted in the jury receiving a distorted, incorrect, or an incomplete view of the operative facts, or some undesirable element obtruded itself into the proceedings creating a condition whereby the giving of a just verdict was rendered difficult or impossible. In the latter instances ... the trial court delivered the jury from a passibly erroneous verdict arising from circumstances over which the jury had no control. Under these circumstances there is no usurpation by the court of the prime function of the jury as the trier of the facts." Lind v. Schenley Industries, Inc., 278 F.2d 79, 90 (3d Cir. 1960).
}

${ }^{35} \mathrm{lbid}$. 
The court believes that it must exercise closer supervision over the granting of new trials where no such element is found in order to prevent usurpation by the trial judge of "the prime function of the jury as the trier of the facts." ${ }^{26}$ The court further distinguishes between litigation that is "long and complicated and deals with a subject matter not lying within the ordinary knowledge of jurors"27 and litigation that is "familiar and simple, the evidence relating to ordinary commercial practices, ${ }^{\prime 28}$ stating that the trial judge is permitted to scrutinize the verdict more closely in the former case than in the latter. The Lind case is deemed to fall within the latter category.

Analysis of the court's opinion reveals three rules to guide the trial judge in the granting of new trials: ( $x$ ) the trial judge may grant new trials because of the presence of "undesirable or pernicious elements" in either complex or "familiar and simple" litigation, (2) in complex litigation the trial judge has wide discretion in granting new trials on the ground that the verdict is against the weight of the evidence and (3) the trial judge is restricted, and will be closely supervised by the appellate court, in granting new trials in "familiar and simple" litigation on the ground that the verdict is against the weight of the evidence. Though the court employs new labels, the results that would be obtained under the first two rules generally accord with well-established principles. The last rule, however, is a restrictive departure from prior decisions.

The Third Circuit Court of Appeals purported to seek "ascertainable legal standards,"29 applicable when the trial judge's order granting a new trial is being reviewed for abuse of discretion. Two difficulties arise, however, which seriously limit the efficacy of the Lind formula as an objective "rule of thumb."

In what cases will the fact situation presented be "familiar and simple?" Appellate courts have long recognized that the trial judge is in the best position to ascertain the true nature of the case and the strength and complexity of the evidence presented. ${ }^{30}$ For this reason, some appellate courts utilize a presumption that the trail judge's

${ }^{20}$ Ibid.

${ }^{27}$ Ibid. The court gives as an example of this type of litigation ${ }^{2}$ casc requiring a jury to pass upon the nature of an alleged newly discovered organic compound in an infringement action." $I d$. at $\mathbf{9 x}$.

${ }^{28}$ Ibid.

${ }^{20} I d$. at 88 .

$: \quad{ }^{30}$ The United States Supreme Court has observed that "determination of whether a new trial should be granted or a judgment entered under Rule 50 (b) calls for the judgment in the first instance of the judge who saw and heard the witnesses and has 
opinion of the weight of the evidence is accurate. ${ }^{31}$ Similarly, other courts will reverse the granting of a new trial only upon a showing of "clear" or "palpable", abuse of discretion. ${ }^{32}$ It is significant in this respect that the Lind case cites no federal appellate decision reversing the granting of a new trial after a verdict contrary to the trial judge's opinion of the weight of the evidence. ${ }^{33}$

Moreover, when has an "undesirable or pernicious element" entered into a trial? In actual practice, a number of such elements may be present in a trial. These elements include the obvious ones acknowledged by the court. However, other such elements, more subtle in nature, as, for example, the demeanor of witnesses, suspicions of bias of the jury, or innuendo of questions may, when taken in combination, improperly affect a litigant's status before the jury. Any one of these might not be deemed serious enough to warrant granting a new trial on that ground alone. Under the Lind rule, however, such an element would not fall into the court's "undesirable or pernicious" category unless it alone is prejudicial enough to justify the granting of a new trial. Hence, the trial judge would seem to be precluded from considering such combined elements in deciding on motions for a new trial in "familiar and simple litigation." Yet, these are factors which the trial judge traditionally has been permitted to evaluate independently of the jury's verdict in determining if the verdict is against the weight of the evidence..$^{34}$

It would seem that the broad language of the Lind case was not

the feel of the case which no appellate printed transcript can impart." Cone v. West Virginia Pulp \& Paper Co., 330 U.S. 212, 216 (1947). This spirit is also seen in Mihalchak v. American Dredging Co., 266 F.2d 875 ( $3 \mathrm{~d}$ Cir.), cert. denied, $36 \dot{\mathrm{i}}$ U.S. 901 (r959); Cloud v. Fallis, r ro So. 2d 669 (Fla. 1959); Bresnahan v. Proman, 312 Mass. 97, 43 N.E.2d 336 (1942); Discargar v. City of Seattle, 30 Wash.2d 46r, I91 P.2d 870 (1948).

${ }^{31}$ Ballard v. Pacific Greyhound Lines, 28 Cal. 2d 357, 170 P.2d 465 (1946); Martin v. Stone, 5I So. 2d 33 (Fla. 195r). It would seem that North Carolina has a conclusive presumption to this effect, for its courts will not review the granting of a new trial on the ground in question. Roberts v. Hill, 240 N.C. 373,82 S.E..2d 373 (1954).

${ }^{32}$ Bugdoian v. Union Trust Co., 337 Ill. App. 405, 86 N.E.2d 253 (1949); Schroeder v. Texas Co., 169 Kan. 607, 219 P.2d 1063 (1950); Hartpence v. Grouleff, 15 N.J. 545, I05 A.2d $51_{4}$ (1954); Tupponce v. Pennsylvania R.R., 358 Pa. 589, 57 A.2d 898 (1948).

${ }^{38}$ The dissenting opinion in the Lind case stated that there was no such case in the Third 'Circuit. 278 F.2d at $9 \mathrm{r}$. Independent research has not discovered any federal decision so holding.

${ }^{34}$ See cases cited at note 37 infra. 
necessary to the decision. The court's narrow objection to the trial judge's order granting a new trial was its belief that the trial judge had substituted his opinion of the credibility of the witnesses for that of the jury. Hence, the court held that the trial judge had abused his discretion. $^{35}$ Some federal district judges have felt themselves restricted in this respect, ${ }^{36}$ but the majority of appellate courts allow the trial judge to consider the credibility of witnesses in passing on motions for new trial on the ground in question. ${ }^{37}$ Indeed, the Third Circuit has followed this line of authority in recent decisions. ${ }^{38}$

It is submitted that to deny the trial judge the right to consider the credibility of witnesses in passing on motions for new trial is to confuse the standard to be applied by him when considering motions for directed verdict or judgment n.o.v. with the standard associated with motions for new trial. In passing upon motions in the former category, the trial judge must view all the evidence in the light most favorable to the nonmovant, resolving conflicts in the evidence and drawing all legitimate inferences in favor of that party. ${ }^{39}$ The trial judge's appraisal of the credibility of witnesses is of no consequence, for all doubts as to credibility must be resolved in favor of the non-movant. In contrast, the great majority of state and federal courts take the position that the trial judge may rely upon his own opinion of the weight of the evidence

\footnotetext{
- st "If Lind's testimony and that of Mrs. Kennan; Kaufmann's secretary, was deemed credible, Lind presented a convincing, indeed an overwhelming case. We must conclude that the jury did believe this testimony and that the court below substituted its judgment for that of the jury on this issue and thereby abused its legal discretion." Lind v. Schenley Industries, Inc., 278 F.2d 79, 91 (3d Cir. 1960).

${ }^{30}$ Shirra v. Delaware, L. \& W. R.R., 103 F. Supp. 812 (M.D. Pa. 1952); Moore v. Rosecliff Realty Corp., 88 F. Supp. 956 (D.N.J. 1950); American Cooler Co. v. Fay \& Scott, 20 F. Supp. 782 (N.D. Me. 1937); Pringle v. Guild, 119 Fed. 962 (C.C.S.C. 1903).

${ }^{37}$ Altrichter v. Shell Oil Co., 263 F.2d 377 (8th Cir. 1959); Marsh v. Illinois Cent. R.R., 175 F.2d. 498 (5th Cir. 1949); Ballard v. Pacific Greyhound Lines, 28 Cal, 2d 357,.170.P.2d 465 (1946); Cloud v. Fallis, x10 So. 2d 669 (Fla. 1959); Thompson v. Titus, 169 Ohio St. 203, 158 N.E.2d 357 (1959) (per curiam); Wein v. Lucey, 8 I R.I. 434, 104 A.2d 248 (1954).

${ }^{38}$ Zegan v. Central R.R., 266 F.2d rox (3d Cir. 1959); Morris Bros. Lumber Co. v. Eakin, 262 F.2d 259 (3d Cir. 1959); Magee v. General Motors Corp., 213 F.2d 899. (3d Cir. 1954). "The ... [motion for a new trial] requires that the trial judgc evaluate all significant evidence, deciding in the exercise of his own best judgment whether the jury has so disregarded the clear weight of the credible evidence that a new trial is necessary to prevent injustice." Zegan v. Central R.R, supra at 104.

${ }^{89}$ Hanson v. Ford Motor Co:, 278 F.2d. 586 (8th Cir. 1960); Snead v. New York Cent. R.R., 216 F.2d 169 (4th Cir. 1954); Downey v. Union Paving Co., 184 F.2d 48 I (3d Cir. 1949).
} 
when considering a motion for new trial and is not bound by the jury's opinion, as reflected in its verdict. ${ }^{40}$

It must be recognized and accepted that the proper extent of the trial judge's control over the jury verdict cannot be reduced to abstract. "rules of thumb." The trial judge can achieve substantial justice in the particular case only if he is allowed to exercise broad discretion; guided by his judicial training and experience and intimate knowledge of the litigation at hand. Unlike the directed verdict or judgment n.o.v., the granting of a new trial is not a final decision on the merits of a cause of action. Rather, the power and duty to grant a new trial is vested in the trial judge so that he may require reconsideration by another jury when, after giving due deference to the jury verdict, he concludes that the verdict is erroneous. Thus, the granting of new trials on the ground that the verdict is against the weight of the evidence is an "expedient middle ground"42 between the uncontrolled jury and complete judicial usurpation of the jury function.

Broadly stated, the Lind decision would require that an appellate court closely scrutinize the granting of new trials in "familiar and simple litigation" where the trial judge could not point to what the appellate court, reading a record of the proceedings below, would categorize as an "undesirable or pernicious element." . In practical effect, the trial judge often could choose only between the limited alternatives of permitting the jury verdict to stand or of granting a judgment n.o.v. Narrowly stated, the Lind decision would prevent the trial judge from considering the credibility of witnesses in deciding on motions for new trial on the ground that the verdict is against the weight of the evidence. To the extent that this decision, under either of the above interpretations, restricts the expedient middle ground of the new trial, it does not merit adoption by other appellate courts.

${ }^{\circ 0}$ Altrichter v. Shell Oil Co., 263 F.2d 377 (8th Cir. 1959); Moist Cold Refrigerator Co. v. Lou Johnson Co., 249 F.2d 246 (9th Cir.), cert. denied, 356 U.S. 968 (1958); Snead v. New York Cent. R.R., '216 F.2d 169 (4th Cir. 1954); Marsh v. Illinois Cent. R.R., 175 F.2d 498 (5th Cir. 1949); Felton v. Spiro, 78 Fed. 576 (6th Cir. x897); Heedman v. Kelsey, $4 x_{4}$ IIl. 453 , xI I N.E.2d 538 (x953); Roberts v. Hill, 240 N.C. 373,82 S.E.2d 373 (1954); 3 Barron \& Holtzoff, Federal Practice AND Procendure § 1302, at 339 (rev. ed. 1958).

${ }^{* 1}$ Professor Moore has stated that: "No rigid or fixed formula can or should prescribe how this principle is to be universally applied. The trial court, which has a feel for the case, should apply the principle so that substantial justice is done on the facts of the individual case." 6 MOORE, FEDERAL PRACTiCe I 59.05[5], at 3756 (2d ed. 1951).

${ }^{42}$ Lind v. Schenley Industries; Inc., $278 \mathrm{~F}: 2 \mathrm{~d} 79,91$ (3d Cir. 1960). 